\title{
METHODOLOGY AND PROBLEMS OF SEISMIC HAZARD ASSESSMENT IN REGIONS WITH LOW SEISMIC ACTIVITY
}

\author{
Kateřina DEMJANČUKOVÁ ${ }^{1}$
}

Review article

\begin{tabular}{|c|c|}
\hline Abstract: & $\begin{array}{l}\text { Despite the fact that the intensity of earthquakes observed in Czech Republic is usually } \\
\text { considered as low, all the critical facilities as chemical industrial objects, nuclear power } \\
\text { plants, large dams, bridges etc. have to meet the safety requirements and standards for } \\
\text { external hazards including earthquakes. Seismic hazard assessment is a site specific } \\
\text { process in which the so called diffuse seismicity has to be included in addition to region, } \\
\text { near region, site vicinity and site area evaluation. }\end{array}$ \\
\hline & $\begin{array}{l}\text { In the paper, methodology and important steps of seismic hazard assessment are presented } \\
\text { according to International Atomic Energy Agency (IAEA) standards with an example of } \\
\text { application for the case of nuclear power plant. }\end{array}$ \\
\hline Keywords: & $\begin{array}{l}\text { Seismic hazard, SSG-9, diffuse seismicity, deterministic (probabilistic) approach, PSA } \\
\text { approach. }\end{array}$ \\
\hline
\end{tabular}

\section{Introduction}

In most of the industrialized countries, standards and requirements for technological systems and other key objects were created simultaneously with continuing development of industry and society. Earthquake has to be involved into considerations during the design phase of the project, not only for specific critical objects and industrial complexes which can endanger their surroundings and also themselves in case of damage. Protection against earthquake in form of application of technical measures has to be ensured by legislation in each country. The emphasis on compliance of standards is important namely because of finance. Increase of the building resistance of half a degree of macroseismic scale means doubling the costs (Procházková, 2008).

Approaches used for seismic hazard assessment are based on deterministic and probabilistic approach. Results of the deterministic approach are often considered too conservative and there is strong effort to reach more realistic results using the probabilistic method. The specialists agree that both of the approaches have to be used to find the optimal result and there is also need of good engineering practise

The requirements of the International Atomic Energy Agency (IAEA) are presented in the so called Safety Guides. For the seismic events, it is the Safety Guide SSG-9 Seismic Hazards in Site Evaluation for Nuclear Installations (IAEA, 2010), issued by IAEA in 2010.

\section{Materials and methods}

An earthquake is a physical phenomenon that is results of dynamic processes in the Earth's interior. If the accumulated energy amount in the given volume exceeds the physical material limits (stress limit, phase transition limit), it releases suddenly of mechanical, thermal and seismic energy. Each earthquake is a unique event that has to be registered through several data - geographical coordinates, epicentral depth, time of occurrence, size, orientation of forces in the epicentre, prevailing force multipole, stress drop due to rupture, size of the irreversible deformation of the epicentre and its time-dependent graph, shape of the damaged area and its size and also distribution of earthquake effects (Procházková, 2008).

The epicentres of earthquakes are not distributed uniformly. It is possible to associate epicentres of earthquakes into the so called focal regions provided that the knowledge of tectonic and geological structures is available. In Fig. 1, the map of focal regions for central Europe is shown including the shape of the territory of Czech Republic (Procházková, 1984).

The seismic activity at the territory of Czech Republic is usually considered as low. The earthquakes registered usually didn't exceed the maximum intensity of $7^{\circ}$ MSK-64 (macroseismic scale). It can be seen in Fig. 2, where the map of maximum observed intensities is presented (Procházková, 2008). The map of maximum 
observed intensities was created based on collection of historical earthquakes followed by data validation and data treatment.

In 2010 International Atomic Energy Agency issued a specific safety guide SSG-9 Seismic Hazards in Site Evaluation for Nuclear Installations. The key chapters are focused on general recommendations, necessary information and investigations (database), construction of a regional seismotectonic model, evaluation of the ground motion hazard, probabilistic seismic hazards analysis (PSHA), deterministic seismic hazards analysis, potential for fault displacement at the site, design basis ground motion, fault displacement and other hazards, evaluation of seismic hazards for nuclear installations other than NPPs.

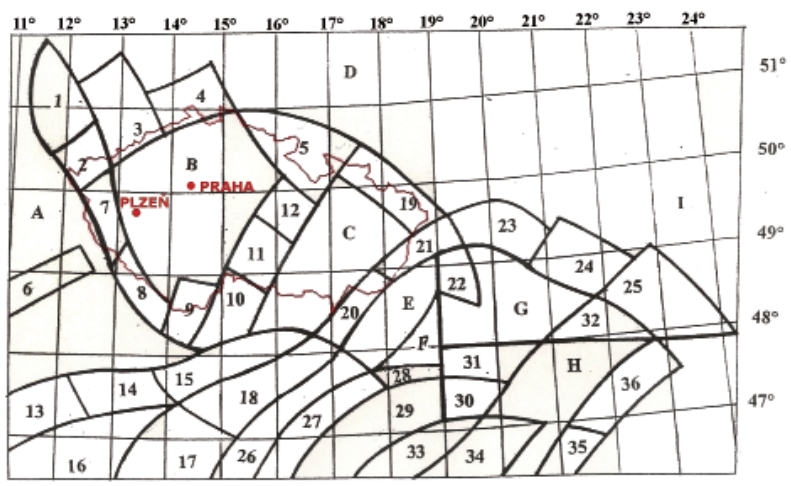

Fig. 1 Map of focal regions for Central Europe (Procházková, 1984)

\section{Diffuse seismicity}

Our findings show that apart from the focal provinces there are broad areas (continental shields), on which the sporadic scattered earthquake foci occur. They are not connected with the expressive fault structures of regional sense, but only with the structures of local sense, on which from time to time the limit rock massif strength may be exceeded. With regard to the reality that the local structures are not extensive, they can only accumulate a small amount of energy that corresponds to their dimensions. The earthquakes on these structures are small; we define them as regions with the diffuse seismicity. Important situation can occur in case of association of diffuse seismicity with a source of induced seismicity which can cause the initiation of strong earthquake, e.g. Asuan (1981), Gazli (1986). In Fig. 1 , the regions with the diffuse seismicity are marked with capital letters A, B, C, etc.

Detail investigation of weak earthquakes inside the Bohemian Massif (Procházková, 1981-1989) showed that these earthquakes are very weak, they have focal depth to $3 \mathrm{~km}$, their occurrence is very non-regular and sparse, and they are connected with very shallow geological structures, the direction of which is different from regional tectonic structures (Procházková and Roth, 1993). Both regions with diffuse seismicity in the Bohemian Massif are surrounded by active focal zones.

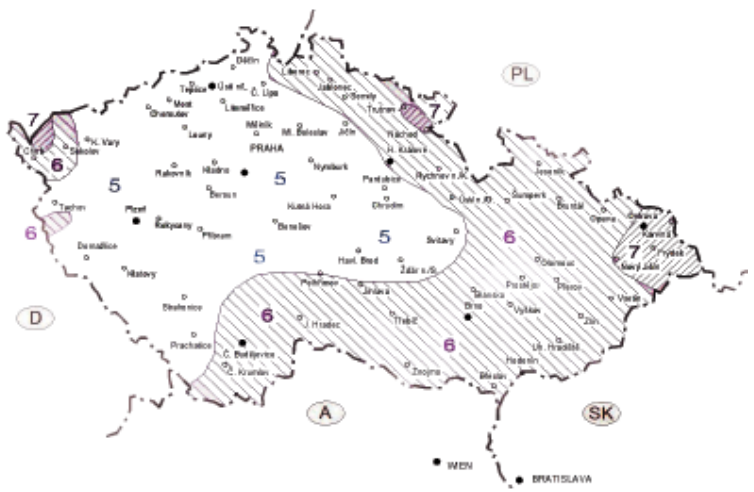

Fig. 2 Map of maximum observed intensities (densely hatched $-7^{\circ}$ MSK-64, sparsely hatched

- $6^{\circ}$ MSK-64, non hatched - $5^{\circ}$ MSK-64)

(Procházková, 2008)

\section{IAEA requirements}

The requirement of seismic hazard assessment for locality selected for nuclear facility is included in the third part of document NS-R-3 (IAEA, 2003) defining specific requirements for external hazards assessment. The duty of identification of risks resulting from external hazards is presented in article 2.7 of the document. Next specific requirements of assessment of individual hazards including earthquake are described in following articles, for the case of earthquake in articles 3.1 to 3.4 of the document (IAEA, 2003):

3.1 The seismological and geological conditions in the region and the engineering geological aspects and geotechnical aspects of the proposed site area shall be evaluated.

3.2 Information on prehistorical, historical and instrumentally recorded earthquakes in the region shall be collected and documented.

3.3 The hazards associated with earthquakes shall be determined by means of seismotectonic evaluation of the region with the use to the greatest possible extent of the information collected.

3.4 Hazards due to earthquake induced ground motion shall be assessed for the site with account taken of the seismotectonic characteristics of the region and specific site conditions. A thorough uncertainty analysis shall be performed as part of the evaluation of seismic hazards. 
All the preceding rules are also included in the article 3.7 of the Safety Guide SSG-9 (IAEA, 2010) where the region is defined as a circle with radius of $300 \mathrm{~km}$ and the selected locality in the centre. The distance of $300 \mathrm{~km}$ should not be always sufficient. It is necessary to consider geological situation of the region and take into account specific parameters of attenuation of intensity of earthquake with distance. If the value of parameter of attenuation of intensity with distance is low, the radius of region should be enlarged adequately. The process of analysis of seismic hazard for a locality of a nuclear power plant can be divided into four phases; see Fig. 3 (Demjančuková, 2013).

Notes to Fig 3:

a) The value of SL-2 represents the Safe Shutdown Earthquake (SSE). It is the so called Maximum Design Earthquake (MDE) which has the frequency of occurrence in the interval $1.10^{-3}$ to $1.10^{-4}$ (for the mean value) or $1.10^{-4}$ to $1.10^{-5}$ (for median) per reactor per year, see (IAEA, 2003), article 2.3, note 4 . The value of SL-2 represents the maximum possible intensity of earthquake in the locality.

b) The value of SL-1 represents the Operating Basis Earthquake (OBE). It is the so called Design Earthquake (DE) which has the probability of occurrence usually $1.10^{-2}$ (for the mean value) per reactor per year. The value of SL-1 characterizes the less serious but more probable event than the value SL-2.

c) The values of SL-1 and SL-2 are the input data for creation of seismic hazard curves by the seismotectonic method.

\section{Results}

\section{Important points of calculation of seismic hazard for regions with diffuse seismicity}

An example of calculation of seismic hazard for a real locality was presented in previous works (Demjančuková, 2012a), (Demjančuková, 2012b) and (Procházková and Demjančuková, 2012) . For the calculation both approaches - deterministic and probabilistic - were used and also seismic hazard calculated according to IAEA requirements for seismic probabilistic safety assessment (PSA) was presented. The comparison of values calculated for a selected locality in Southern Bohemia is shown in Tab. 1.
Tab. 1 Comparison of seismic hazard values calculated for selected locality in Southern Bohemia by different methods

\begin{tabular}{|c|c|c|c|}
\hline $\begin{array}{c}\text { Time } \\
\text { interval } \\
\text { [years] }\end{array}$ & $\begin{array}{c}\text { Deterministic } \\
\text { approach } \\
{\left[{ }^{\mathbf{}} \text { MSK-64] }\right.}\end{array}$ & $\begin{array}{c}\text { Probabilistic } \\
\text { approach (median } \\
+\boldsymbol{\sigma})\end{array}$ & $\begin{array}{c}{ }^{\mathbf{}} \text { MSK-64] } \\
\text { SPSA } \\
{\left[{ }^{\circ} \text { MSK-64] }\right.}\end{array}$ \\
\hline 50 & 5.5 & 5.2 & 5.3 \\
\hline 100 & 5.7 & 5.3 & 5.5 \\
\hline 10000 & 6.1 & 5.5 & 5.9 \\
\hline
\end{tabular}

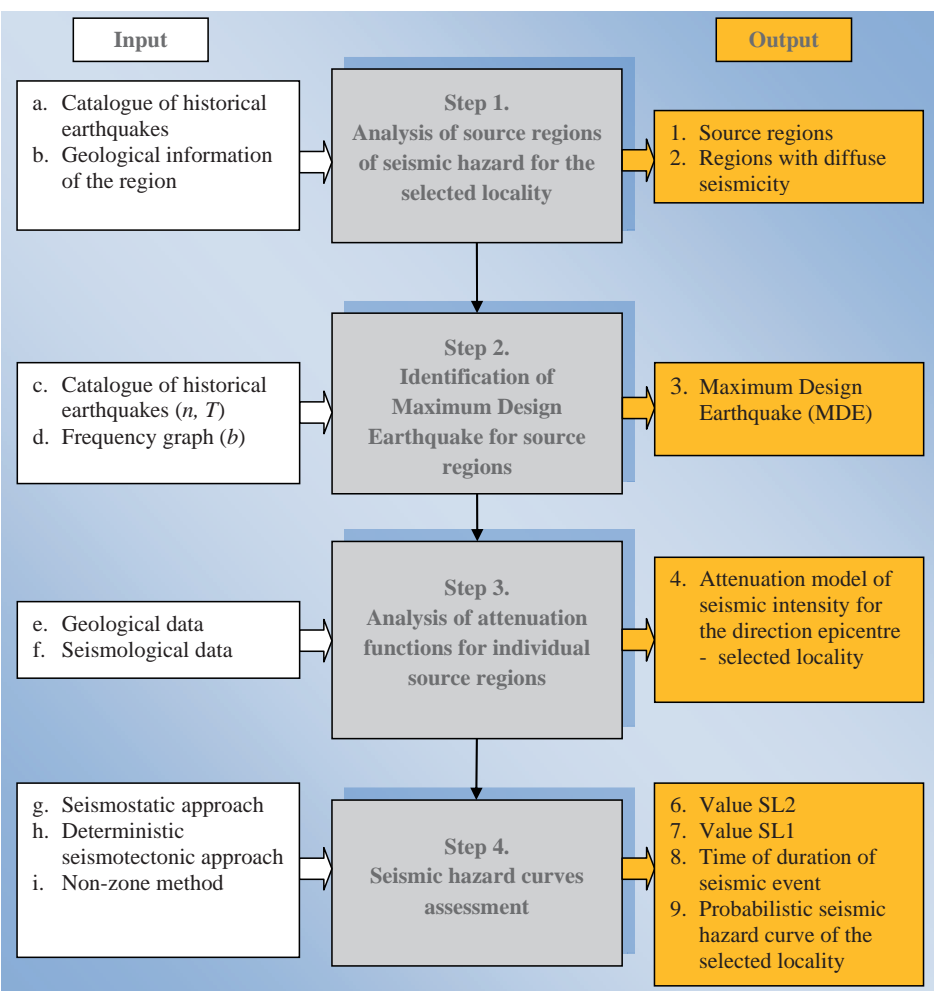

Fig. 3 Scheme of the process of seismic hazard analysis for nuclear power plant (Demjančuková, 2013)

In the next steps, the diffuse seismicity should be included in the assessment. In Tab. 2, an example of a record of diffuse seismicity from the calatogue (Procházková and Šimůnek, 1998) is presented.

Tab. 2 Example of diffuse seismicity record (Procházková and Šimůnek, 1998)

\begin{tabular}{|c|c|c|c|}
\hline \multirow{2}{*}{ Date } & \multirow{2}{*}{ Time [GMT] } & \multicolumn{2}{|c|}{ Epicentre Coordinates } \\
\cline { 3 - 4 } & & ${ }^{\circ} \mathrm{N}$ & ${ }^{\circ} \mathrm{E}$ \\
\hline 20.3 .1784 & & 50.60 & 13.70 \\
\hline & & Magnitudo & Note \\
\hline $\begin{array}{c}\text { Epicentre } \\
\text { Depth }\end{array}$ & $\begin{array}{c}\text { Intensity in } \\
\text { Epicentre }\end{array}$ & M & $\begin{array}{c}\text { Focal } \\
\text { Region }\end{array}$ \\
\hline$[\mathrm{km}]$ & $\mathrm{I}_{\mathrm{o}}{ }^{\circ}[\mathrm{MSK}-64]$ & & $\mathrm{B}$ \\
\hline & 7 & & \multicolumn{2}{c}{} \\
\hline
\end{tabular}


According to the SSG-9 (IAEA, 2010) document, for the nuclear facility placed in a locality with diffuse seismicity, it is necessary to:

a) For each seismogenic structure, the maximum potential magnitude should be assumed to occur at the point of the structure closest to the site area of the nuclear power plant, with account taken of the physical dimensions of the seismic source. When the site is within the boundaries of a seismogenic structure, the maximum potential magnitude should be assumed to occur beneath the site. In this case, special care should be taken to demonstrate that the seismogenic structure is not capable.

b) The maximum potential magnitude associated with zones of diffuse seismicity in each adjoining seismotectonic province should be assumed to occur at the point of the province boundary closest to the site.

Special attention has to be paid to the faults near the selected locality. It is important to prove that there are not faults near the locality and if there are some, the data, explorations and results of analyses have to show that the fault is not active. The distance from locality for explorations of faults is usually selected by units of kilometres.

\section{Conclusion}

Methods of calculation of seismic hazard if a selected locality were presented in previous works. The diffuse seismicity which has to be involved in the seismic hazard assessment requires complex approach and brings more uncertainties (knowledge uncertainties) in data recorded due to distribution of epicentres of earthquakes. The knowledge of local conditions, geological and seismological analyses, presence of active and inactive faults for possible diffuse seismicity occurrence is necessary. The diffuse seismicity is a manifestation of energy accumulated and released from local geological structures.

It is necessary to use data from many branches, several experts and specialized methods, e.g. Delphi method. The key point of seismic hazard assessment for a selected locality in area with diffuse seismicity is input data.

\section{Acknowledgments}

I would like to thank the University of West Bohemia for the financial support (project SGS2014-070) and I would like to thank doc. RNDr. Dana Prochazkova, DrSc. for leadership of my work.

\section{References}

DEMJANČUKOVÁ, Kateřina (2012a). Metody stanovení seismického ohrožení při výběru lokality pro technologická zařízení. In: Sborník prednášek XI. ročníku mezinárodni konference Ochrana obyvatelstva - Nebezpečné látky 2012. [CD-ROM]. Ostrava: Sdružení požárního a bezpečnostního inženýrství, 2012, s. 32-34. ISBN 978-80-7385-109-5. (in Czech)

DEMJANČUKOVÁ, Kateřina (2012b). Srovnání výsledků pravděpodobnostního a deterministického hodnocení seismického ohrožení v západočeské metropoli. In: Sborník přednášek XXI. mezinárodní konference Požární ochrana 2012. [CD-ROM]. Ostrava: Sdružení požárního a bezpečnostního inženýrství, 2012, s. 35-37. ISBN 978-80-7385-115-6. (in Czech)

DEMJANČUKOVÁ, Kateřina (2013). Metodika stanovení seismického ohrožení vybrané lokality. Výzkumná zpráva ev. č.FR-TI1/ 423. ÚJV Řež, a.s. 2013. (in Czech)

IAEA (2003). Site Evaluation for Nuclear Installations. Safety Requirements. IAEA Safety Standards Series No. NS-R-3. Vienna, International Atomic Energy Agency, 2003. ISBN 92-0-112403-1.

IAEA (2010). Specific Safety Guide SSG-9, Seismic Hazards in Site Evaluation for Nuclear Installations. Vienna, International Atomic Energy Agency, 2010. ISBN 978-92-0-102910-2.

PROCHÁZKOVÁ, Dana (1981-1989). Catalogue of Earthquakes. Bohemia and Moravia. 1981 - 1989. Ministerstvo hospodářství, Praha 1993, 637p. (in Czech)

PROCHÁZKOVÁ, Dana (1984). Analýza zemětřesení ve Střední Evropě. Doktorská disertační práce. GFÚ ČSAV, Praha 1984, 486p. (in Czech)

PROCHÁZKOVÁ, Dana, ROTH, Zdeněk (1993). Complex Investigation of Earthquakes in Central Europe. In: Environmental Monitoring and Adjacent Problems. Czech Ecol. Inst. and Ministry of Environment, p. 287349. Praha 1993.

PROCHÁZKOVÁ, Dana, ŠIMŮNEK, Pavel (1998). Fundamental Data for Determination of Seismic Hazard of Localities in Central Europe. Praha 1998.132 p. ISBN 80-238-2661-1. 
PROCHÁZKOVÁ, Dana (2008). Seismické inženýrství na prahu třetího tisíciletí. SPEKTRUM, Ostrava, 2007, roč. XII, 25p. ISSN 1211-6920. (in Czech)

PROCHÁZKOVÁ, Dana (2011). Metody, nástroje a techniky pro rizikové inženýrství. ČVUT, Praha 2011.369p. ISBN 978-80-01-04842-9. (in Czech)

PROCHÁZKOVÁ, Dana, DEMJANČUKOVÁ, Kateřina (2012). Seismic Hazard Assessment for Selected Real Locality in Central Europe - Critical Points of Assessment. In: Proceedings of the conference Safe 2012, Helsinki, 2012. ISBN 978-92-95064-15-7. 